\title{
ЗАЛУЧЕННЯ СПЕЦІАЛІСТІВ ДО ПРОВЕДЕННЯ ОГЛЯДУ ПРИ РОЗСЛІДУВАННІ НЕЗАКОННОГО ПОВОДЖЕННЯ ЗІ ЗБРОЕЮ
}

\section{БОРИСОВ Станіслав Геннадійович - здобувач Інституту права та суспільних відносин Відкритого міжнародного університету розвитку людини «Україна" \\ DOI:10.32782/NP.2019.4.31 \\ УДК 343.985.4}

\begin{abstract}
B статье рассмотренъ проблемнъие вопросы, возникающие в ходе привлечения спечиалистов к проведению осмотра при расследовании незаконного обращения с оружием, боевълм припасами или взрьгвчатыми веществами. Проанализированъ этапь и стадии проведения осмотра и данъ рекомендации по деятельности специалистов: криминалиста, оружиеведа, взрыльотехника на каждой из них. Обрашается внимание на необходимость, наряду со специальными знаниями, применять современные технико-криминалистические средства обнаружения, биксации, изгятия и предварительного исследования доказательств на месте происшествия. Сосредоточено внимание на взаимодействии следователя со специалистами, исходя из руководящей роли следователя при проведении следственного действия.

Ключевъие слова: уголовное преступление, специальнъие знания, специалист, обзор, оружие, боеприпасъ, взрьичатье вещества, незаконное обращение с оружием.
\end{abstract}

\section{Постановка проблеми}

Сучасний стан соціально-економічного та науково-технічного розвитку суспільства певним чином впливає на криміногенну ситуацію в Україні. Негативним аспектом є професіоналізація злочинності, підвищення рівня організації вчинення злочинів, збільшення технічного оснащення злочинних груп. 3 іншого боку, це спонукає правоохоронні органи на протидію злочинності впроваджувати нові сучасні науково-техніч- ні засоби. Змінюється і структура злочинності у напрямку збільшення корисливо-насильницьких злочинів, вчинюваних 3 використанням зброї та вибухових пристроїв. Події останніх років, пов'язаних з веденням бойових дій на сході країни, сприяють незаконному обігу зброї, боєприпасів, вибухівок.

При розслідуванні незаконного поводження зі зброєю, бойовими припасами або вибуховими речовинами однією 3 найвагоміших слідчих (розшукових) дій є огляд. Ця дія проводиться, як правило, на початковому етапі розслідування. Від іï ефективності залежить повнота та швидкість подальшого розслідування. Розробка та вдосконалення тактики використання спеціальних знань при огляді місця події, поряд із застосуванням сучасних науково-технічних засобів, $\epsilon$ перспективним напрямком для наукових розробок та визначає актуальність розглядуваної проблеми.

Аналіз публікацій, у яких започатковано розв'язання даної проблеми

Розробці та вдосконаленню організаційно-тактичних прийомів огляду присвячені праці багатьох українських учених-криміналістів: В. П. Бахіна, А. Ф. Волобуєва, В. А. Журавеля, А. В. Іщенка, В. О. Коновалової, Н. І. Клименко, В. С. Кузьмічова, Є. Д. Аук'янчикова, В. Г. Аукашевича, М. В. Салтевського, Р. А. Степанюка, В. В. Тіщенка, А. Д. Удалової, В. В. Циркаля, К. О. Чаплинського, С. С. Чернявського, Ю. М. Черноус, В. М. Шевчука, В. Ю. ШІе- 
пітька та ін. Однак досі недостатньо розроблена організація і тактика огляду із залученням спеціалістів при розслідуванні незаконного поводження зі зброєю, бойовими припасами або вибуховими речовинами.

Метою статті $\epsilon$ розробка алгоритму дій спеціаліста під час огляду місця події при розслідуванні незаконного поводження зі зброєю, бойовими припасами або вибуховими речовинами.

Загальновідомо, що будь-яка слідча (розшукова) дія, у тому числі огляд, складається з підготовчого, робочого та заключного етапів. Спеціаліст-криміналіст допомагає слідчому вже на підготовчій стадії огляду ще до виїзду на місце події. Він бере участь в аналізі отриманої первинної інформації, консультує слідчого з питань техніко-криміналістичного забезпечення огляду, доцільної, на його думку, послідовності дій, висловлює пропозиції щодо залучення інших спеціалістів. Після цього спеціаліст-криміналіст готує необхідні техніко-криміналістичні засоби.

Ми приєднуємось до думки А. М. Аазебного, який зазначає: «Незалежно від наявності спеціальних криміналістичних знань в особи, що проводить слідчі (розшукові) дії з участю спеціаліста-криміналіста, доцільно завжди доручати застосування техніко-криміналістичних засобів і методів спеціалісту. Така організація роботи дозволить особі, що здійснює досудове розслідування, зосередити свої сили на вирішенні процесуальних та організаційно-тактичних питань слідчої (розшукової) дії, що ним проводиться». За даними дослідження науковця, 90 \% опитаних слідчих, «самостійне застосування ними техніко-криміналістичних засобів і методів відволікає їх від загального керівництва слідчими (розшуковими) діями і складання їх протоколу. Ускладнення науково-технічних засобів і методів роботи 3 доказами не дозволяе слідчому оволодіти всіма криміналістичними рекомендаціями, тому необхідно іти по шляху звільнення слідчого (оперативного працівника) від усіх технічних операцій по роботі 3 доказами, поклавши обов'язок із застосування криміналістичної техніки на спеціаліста-криміналіста» [1, с. 138-139]. Крім того, зважаючи на швидкий розвиток техніко-криміналістичних засобів, окремі з них потребують знання та вміння, якими не може володіти слідчий.

Після прибуття на місце події спеціалісткриміналіст разом зі слідчим визначають межі огляду, вирішують питання щодо способів огляду, ділянок, на яких зосереджена максимальна кількість слідів та виявлення й вилучення яких потребує застосування криміналістичної техніки. При визначенні меж огляду часто допускаються помилки у випадках механічного фіксування слідів і обстановки на місці події, без їх грунтовного аналізу та осмислення. Саме характер події і обстановка визначають у кожному конкретному випадку межі території, яка повинна ретельно оглядатися. Через необгрунтоване звуження меж огляду залишаються без огляду ті ділянки місцевості, на яких можуть знаходитися об'єкти зі слідами злочину та сліди злочинця. Саме у визначенні таких об'єктів доречна допомога спеціаліста.

На підготовчій стадії після прибуття на місце події спеціаліст разом зі слідчим оцінюе ступінь організації охорони місця події та приймає заходи з видалення сторонніх осіб з місця події. У разі, якщо буде з'ясовано, що на місці події перебували сторонні особи, потрібно встановити, на яких об'єктах вони могли залишити сліди. На цій стадії, на думку В. В. Коваленка, доцільна участь спеціаліста-криміналіста в опитуванні очевидців і осіб, які першими знайшли сліди злочинної події. При цьому в них треба з'ясувати про внесені в обстановку місця події зміни, і якщо такі $\epsilon$, то коли, ким, 3 якою метою і що саме було змінено, які сліди й об'єкти і де були виявлені. Отримана з таких джерел і проаналізована на основі спеціальних криміналістичних знань інформація може надати допомогу в попередньому встановленні меж місця події, у визначенні послідовності й тактики проведення огляду, у висуванні загальних версій про подію, що сталася, тощо [2, с. 99].

Під час робочого етапу огляду місця події спеціаліст-криміналіст надає криміналістичну і технічну допомогу слідчому, що полягає у безпосередньому застосовуванні техніко-криміналістичних засобів, прийомів та методів для виявлення, фіксації та вилу- 
чення слідів злочину. Як слушно зазначають В. П. Бахін та В. Г. Гончаренко, «виявлення і фіксація слідів - одна з основоположних операцій слідчої діяльності, яка значною мірою визначає позитивний чи негативний результат розслідування. Для утворення і виявлення слідів характерними $є$ певні закономірності, врахування і використання яких дозволяє вести цілеспрямований збір доказової інформації. Найбільш важлива роль серед них належить закономірностям, які виявляються в утворенні слідів взаємодії і взаємовідображення об'єктів, що пов'язані з подією злочину. Керуючись ними, слідчий шукає і використовує сліди перебування особи на місці події, сліди застосування певних знарядь, сліди дій конкретним способом тощо» $[3$, с. 5$]$.

Будь-який слід несе певну інформацію про вчинений злочин. Р. С. Бєлкін поділяв інформацію, носієм котрої є слід, на особистісну (інформацію про людину як об'єкт чи суб'єкт процесу слідоутворення), речову (інформацію щодо відображуваного та такого, що відображує, предметів) й операційну (інформація про операцію, що призвела до утворення сліду, тобто про механізм слідоутворення) [4, с. 63]. Аналізувати таку інформацію шляхом вивчення ознак та властивостей виявлених слідів допомагає слідчому спеціаліст-криміналіст. При проведенні огляду спочатку потрібно звертати увагу та вилучати ті сліди, які виявлено на шляху руху слідчо-оперативної групи для запобігання їх знищення. Це перш за все сліди, виявлені на грунті або підлозі. Під час загального огляду спеціаліст разом зі слідчим визначають способи огляду, об'єкти обстановки, що будуть підлягати детальному огляду, та предмети, на яких потрібно виявляти сліди. На цій стадії спеціалістом проводиться орієнтуюча, оглядова та вузлова фотозйомки. При огляді виявлених на місці події зброї боєприпасів, вибухових пристроїв, інструментів та матеріалів, що могли бути використані при їх виготовленні, проводиться аналіз та оцінка приналежності їх до події злочину.

Стадія детального огляду в тактичному плані є складнішою у зв'язку з більшим об'ємом виконуваною слідчим і спеціалістом роботи. На цій стадії спеціаліст-криміналіст проводить наступні дії: послідовно та всебічно вивчає деталі обстановки місця події та кожний предмет та слід окремо; визначає об'єкти і сліди, які потрібно вилучити; визначає техніко-криміналістичні засоби та методи, що необхідні для вилучення слідів; проводить необхідні вимірювання; робить детальну фотозйомку об'єктів. Слідчий повинен враховувати, що процес застосування техніко-криміналістичних методів і засобів трудомісткий та вимагає певного часу. Тому 3 метою планування проведення огляду, слідчий зобов'язаний з'ясувати у спеціаліста-криміналіста приблизний час, протягом якого буде здійснюватися застосування техніко-криміналістичних засобів і методів. Протягом цього часу слідчий не повинен підганяти спеціаліста-криміналіста і може зайнятися вирішенням організаційно-тактичних та процесуальних питань огляду.

При виявленні зброї на місці події визначається ії модель, система, калібр. Звертають увагу на особливості ії конструкції і зовнішній стан механізмів, наявність на зовнішній поверхні слідів пальців рук, крові тощо. Огляд вогнепальної зброї, ії частин та механізмів здійснюється 3 дотриманням правил безпеки. Спочатку потрібно 3'ясувати знаходження ударно-спускового механізму на запобіжнику та положення курка. Потім встановлюється наявність патрона у патроннику для чого в автоматичній зброї виймають магазин, після чого, утримуючи пальцями за рифлену поверхню, відводять затвор назад. При наявності патрона його вилучають, після чого затвор повертається у початкове положення. Оглядаючи зброю, особливо кустарного виготовлення чи перероблену, необхідно мати на увазі, що можливе здійснення пострілів без натиску на спускової гачок, тому не можна направляти зброю стволом у напрямку людей. Під час огляду револьверів відзначають положення барабану та наявність у ньому набоїв і стріляних гільз. В автоматах з'ясовують положення затвора і встановлюють, чи знаходиться затвор на запобіжнику. Також відзначають положення перемикача режиму вогню: чи знаходиться він у положенні автоматичної або одиночної стрільби. 


\section{Дискусії, обговорення, актуально}

При огляді гвинтівок і карабінів необхідно встановити: відкритий чи закритий затвор. Якщо закритий, то встановлюють спущений курок чи зведений або поставлений на запобіжник [5, с. 190]. Якщо зброя оглядається на місці події, в практиці розслідування трапляються випадки нехтування означеними вище правилами, що призводить іноді до негативних наслідків. При огляді боєприпасів до вогнепальної зброї звертають увагу на їх кількість, форму куль та гільз, їх розміри, метал, з якого виготовлені, стан поверхні.

При виявленні на місці події значної кількості зброї та боєприпасів на практиці трапляються випадки поверхневого їх огляду, без приділення уваги залишеним на них слідах. Іноді обмежуються лише зовнішнім оглядом 3 фіксацією номерів на зброї. На наш погляд, такі дії не є правильними. Бажано відразу на місці події оглядати зброю у повному обсязі з вилученням усіх можливих слідів. Однак, іноді зброя та боєприпаси зберігаються у несприятливих для огляду умовах: вологі чи темні приміщення (підвали, гаражі, земельні схованки) або огляд проводиться у несприятливих погодно-кліматичних умовах, що ускладнюе процес виявлення та вилучення слідів. Вважаємо, що за таких умов допустимо вилучення при огляді місця події зброї та боєприпасів із зазначенням їх кількості та індивідуальних ознак (номерних знаків) 3 подальшим іï оглядом окремо.

Під час огляду вогнепальної зброї необхідно встановити та зафіксувати в протоколі наступні дані: а) вид зброї: револьвер, пістолет, гвинтівка тощо; б) система та калібр зброї; якщо їх встановлення ускладнено, то необхідно вказати форму та розміри; в) положення частин зброї - чи зведений курок, чи поставлена зброя на запобіжник, чи 6 у каналі ствола патрон; г) наявність або відсутність на зброї відбитків пальців; г) інші сліди - забруднення, змащення тощо; д) наявність або відсутність специфічного запаху пороху, що згорів у каналі ствола; е) серію, номер та рік випуску зброї; заводські номери можуть бути на декількох деталях, у зв'язку з чим слід мати на увазі, що злочинець, знищивши номер на одній деталі, забуває інколи зробити це на інших; якщо зброя зібрана з різних деталей, то вказують усі номери; якщо номери забиті, то цей факт необхідно зафіксувати у протоколі, щоб надалі призначити експертизу зі встановлення номерів; є) зовнішній вигляд зброї, зокрема грубо оброблена поверхня свідчить про саморобний спосіб виготовлення, а заіржавлена поверхня про те, що зброя зберігалась у сирому місці та ін.; ж) індивідуальні особливості зброї; на ній можуть бути вигравірувані написи, ініціали тощо; до них належить колір фарбування рукоятки або прикладу, колір і якість ременя, подряпини, вм'ятини тощо; з) упаковка зброї, зокрема їі характер, спосіб виготовлення, стан, характер матеріалу, можливість використання тільки для зберігання або ж і для носіння та ін. [6, с. 474].

Огляд саморобної вогнепальної зброї починається 3 вивчення досліджуваного об'єкта з метою його індивідуалізації. При цьому звертається увага на ті особливості зброї, які дозволяють відрізнити ії від усіх інших екземплярів зброї. На саморобній зброї, залежно від способу їі виготовлення, маркування може бути відсутнім, тому необхідно вказати матеріал, з якого виготовлено зброю або його окремі деталі, розміри, вагу, вказати на особливості зовнішнього вигляду, форми обробки, написи, подряпини, забоїни металу тощо. Потім досліджується взаєморозташування частин саморобної вогнепальної зброї, їх стан, взаємодія, наявність порохової кіптяви в каналі ствола та ін. При описі саморобної вогнепальної зброї не слід забувати про такі «дрібниці», як наявність наскрізного каналу ствола, діючої пружини, спускового гачка і т. П. При огляді особливу увагу слід звертати на наявність ствола або слідів його кріплення. Ствол у вигляді самостійної деталі може зберігатися окремо і може бути приєднаний до зброї тільки в потрібний момент [7, с. 127-128].

Під час огляду зброї та боєприпасів як спеціалісти-криміналісти на практиці залучаються інспектори-криміналісти слідчих підрозділів поліції або співробітники НДЕКЦ МВС України. Вони, як правило, володіють спеціальними знаннями у галузях зброєзнавства, трасології, технічного дослідження документів та інших, необхідних для проведення якісного огляду. Од- 
нак, аналіз протоколів огляду свідчить про їх більшу інформативність у випадках, коли до огляду залучаються працівники НДЕКЦ.

В органах поліції порядок залучення працівників органів досудового розслідування поліції та Експертної служби Міністерства внутрішніх справ України як спеціалістів для участі в проведенні огляду місця події, регламентованій спеціальною Інструкцією, затвердженою наказом МВС України від 03.11.2015 р. № 1339. У ній достатньо повно, на наш погляд, визначено алгоритм дій спеціалістів при огляді місця події. Безпосередньо в Інструкції регламентуються дії спеціаліста на робочому етапі таким чином: «2) прибувши для участі в огляді, спеціалісти отримують від слідчого необхідну інформацію про обставини справи, дії учасників ОМП, здійснені до їх прибуття, завдання, які необхідно вирішити, та надалі виконують доручення слідчого, які стосуються використання його спеціальних знань; 3) на початку огляду слідчий спільно зі спеціалістами визначають межі та порядок проведення огляду, після чого спеціаліст здійснює фотографування та відеозйомку місця події; 4) після отримання доручення слідчого на проведення динамічної стадії ОМП та завдання на виявлення слідової інформації спеціалісти визначають алгоритм пошуку доказів (слідів, речей, документів) і методи їх виявлення, після чого узгоджують свої дії із слідчим та за його погодженням приступають до проведення ОМП; 5) дії спеціалістів, які безпосередньо пов'язані з виявленням, закріпленням та вилученням слідів і речових доказів, здійснюються відповідно до тактики огляду місця події та методики розслідування окремих видів кримінальних правопорушень; 6) перед переміщенням об'єкта (з метою огляду та виявлення слідової інформації) спеціалістом здійснюється його вузлова фотозйомка; 7) під час проведення пошуку та виявлення слідів спеціалісти застосовують наявні технічні засоби та використовують насамперед неруйнівні методи їх виявлення, а в разі недосягнення позитивного результату - руйнівні методи виявлення слідової інформації; 8) перед використанням руйнівних методів пошуку слідів спеціалісти повинні отрима- ти від слідчого згоду на їх застосування та визначитися з пріоритетом слідової інформації, яка підлягає виявленню, з метою подальшого проведення експертних досліджень у лабораторних умовах; 9) про вжиті заходи та факти виявлення слідової інформації спеціалісти інформують слідчого. Під час огляду здійснюються фотографування та вилучення виявлених об'єктів, фіксуються методи їх виявлення із зазначенням про це у протоколі ОМП» [8].

При наявності інформації, що на місці події можуть знаходитись вибухові речовини або пристрої, слідчому необхідно залучати до проведення огляду спеціаліставибухотехніка. Крім спеціальних знань у галузі вибухотехніки, йому потрібно мати при собі різноманітне обладнання для виявлення, вилучення та, в разі необхідності, знешкодження вибухових пристроїв. До таких засобів відносяться: обладнання для контактної та дистанційної фіксації вибухових пристроїв, документування дій вибухотехніків; інструменти для виявлення та видалення 3 місця події вибухових пристроїв (телескопічний роботизований карбоновий маніпулятор, багатоцільові спеціальні набори «Hook \& Line» для роботи 3 вибухонебезпечними предметами, детектори для експрес-аналізу вибухових речовин, роботманіпулятор тощо); вибухозахисне обладнання та спорядження (протиосколкові покривала, захисні маски та костюми); обладнання для контактного та безконтактного знешкодження вибухових пристроїв; засоби для транспортування вибухонебезпечних об'єктів.

На місці події дії спеціаліста направлені, перш за все, на виявлення вибухових речовин та пристроїв, визначення ступеня ïх небезпеки для оточення та планування подальших дій $з$ ними. Якщо при зовнішньому огляді вибухового пристрою вибухотехніком буде визначено, що він є небезпечним, потрібно вжити заходів щодо видалення всіх присутніх 3 місця події. Після цього, здійснивши дистанційну фотозйомку місця розташування пристрою, спеціаліствибухотехнік видаляє його з місця події на небезпечну відстань та вживає заходів для знешкодження. 
Якщо оглянуті вибухові пристрої та речовини не становлять загрози для оточення, спеціаліст-вибухотехнік спрямовує свою діяльність на визначення зовнішніх ознак вибухових об'єктів, виявлення слідів на них, встановлює їх групову належність тощо. За зовнішніми ознаками можна визначити спосіб виготовлення пристрою (промисловий або саморобний), геометричні параметри (форма, розміри), колір, вид матеріалу елементів, фарбування зовнішніх деталей, маркування, сліди технологічних операцій, сліди корозії або механічних ушкоджень, агрегатний стан, розміри та форма часток вибухової речовини. Форма вибухових пристроїв промислового виготовлення та їх елементів індивідуальна для кожної конструкції або виду пристрою. Розмір і маса пристрою є єдиними кількісними характеристиками, що дозволяють проводити діагностику пристрою, використовуючи довідкові відомості. При цьому маса пристрою може дати первісну інформацію про наявність або відсутність у ньому заряду вибухової речовини.

Особливості конструкції оболонки в сукупності з лінійними та ваговими характеристиками пристрою дозволяють оцінити ступінь небезпеки вражаючої дії вибуху по можливому утворенню осколків, а також про використаний для виготовлення матеріал. Масивна металева оболонка характерна для артилерійських снарядів, ручних гранат й інших боєприпасів осколкової дії. Насічка на корпусі типова для осколкових боєприпасів. Тонкі металеві оболонки - для засобів ініціювання, деяких видів імітаційних засобів, інженерних боєприпасів фугасної дії. Фарбування захисного кольору властиве для ручних гранат; чорне - для навчальних гранат, що не містять вибухових речовин. Маркувальні позначки також наносяться фарбою або клеймуванням та можуть вказувати на тип виробу, його спорядження, завод-виготовлювач, рік виготовлення, партію тощо. Сліди технологічних операцій, звичайно, присутні на зовнішніх поверхнях пристрою у вигляді слідів тиску, різання, які можуть бути джерелом інформації про обладнання, інструменти та специфіку виготовлення окремих деталей і вузлів, переважно саморобного виготовлення. Сліди ко- розії й механічних ушкоджень свідчать про порушення правил зберігання пристрою. Наявність подібних ознак вимагає додаткової уваги до забезпечення техніки безпеки при роботі з такими об'єктами.

Для дослідження саморобних вибухових пристроїв на місці події можуть використовуватися переносні рентгенівські установки, наприклад портативні рентгенівські системи «Rayzor X» чи «Spar X». Вони дозволяють вивчити внутрішню будову саморобного підривного пристрою, що забезпечує його успішне знешкодження.

Також спеціаліст може висовувати версії щодо: механізму слідоутворення, матеріальних зв'язків та відношення різних об'єктів до обстановки розслідуваної події, механізму події, що розслідується в цілому й окремих його епізодів; ознак осіб та предметів, які знаходяться або можуть знаходитись у зв'язку з розслідуваною подією; про необхідні невідкладні дії, можливості та методи використання зібраних доказів для розслідування події; доцільність перевірки слідів та об’єктів за інформаційними системами, про призначення певних експертиз об'єктів, зібраних при проведенні слідчих (розшукових) дій, про підбір відповідних призначеним експертизам зразків.

У заключній стадії огляду спеціалісти надають слідчому технічну допомогу, що полягає у фіксації та упаковці вилучених об’єктів, описі їх у протоколі огляду, складанні разом зі слідчим планів, схем, креслень. Вилучені предмети пакуються в конверти або поліетиленові пакети окремо за загальними правилами. Протокол є основним способом фіксації ходу та результатів цієї слідчої (розшукової) дії. Він повинен бути точним, послідовним, повним, об'єктивним, цілеспрямованим і складеним з додержанням вимог закону. Він складається безпосередньо слідчим.

\section{Висновки}

Розглянувши дії спеціаліста на різних стадіях огляду місця події, потрібно зазначити, що результат слідчої дії визначається його професіоналізмом та узгодженістю дій зі слідчим та іншими учасниками розслідування. Відсутність спеціаліста-криміналіста, 


\section{АНОТАЦІЯ}

У статті розглянуто проблемні питання, що виникають під час залучення спечіалістів до проведення огляду при розслідуванні незаконного поводження зі зброєю, бойовими припасами або вибуховими речовинами. Проаналізовано етапи та стадї проведення огляду та надано рекомендаџї щодо діяльності спещіалістів: криміналіста, зброєзнавия, вибухотехніка на кожній з них. Звертається увага на необхідність, поряд зі спеціальними знаннями, застосовувати сучасні техніко-криміналістичні засоби виявлення, біксаціӥ, вилучення та попереднъого дослідження доказів на місиі події. Зосереджено увагу на взаємодї слідчого зі спеціалістами, виходячи з керівної ролі слідчого при проведенні слідчої (розшукової) дї.

Ключові слова: кримінальне правопорушення, спеціальні знання, спеціаліст, огляд, зброя, боєприпаси, вибухові речовини, незаконне поводження зі зброєю.

вибухотехніка під час огляду призводить до того, що не виявляються та не вилучаються об'єкти, які в подальшому могли б бути визнані речовими доказами та щодо яких $\epsilon$ необхідність призначення судових експертиз. Крім того, несвоєчасне вилучення таких об’єктів у ході додаткового чи повторного огляду місця події та несвоєчасне призначення необхідних судових та криміналістичних експертиз щодо вилучених об'єктів призводить до втрати слідів на цих об’єктах та унеможливлює їх використання в подальшому як доказів.

\section{入ітература}

1. Аазебний А. М. Використання спеціальних знань при розслідуванні кримінальних правопорушень проти громадського порядку : дис. ... канд. юрид. наук : 12.00.09. Ірпінь: Університет державної фіскальної служби України, 2016. 227 с.

2. Коваленко В. В. Актуальні проблеми застосування науково-технічних засобів спеціалістами при провадженні слідчих дій : дис. ... канд. юрид. наук : 12.00.09. Київ : Національна академія внутрішніх справ України, 2004. 253 с.

3. Бахін В. П., Гончаренко В. Г. Як розкриваються злочини (Криміналістика у пи-

SUMMARY
The article deals with the problematic issues
that arise when engaging specialists to carry out
an examination when investigating the illicit
handling of weapons, ammunition or explosives.
The stages and stages of the review were analyzed,
and recommendations were given on the activities
of specialists: forensic scientist, weapons expert,
explosive technician at each of them. Attention
is drawn to the need, along with specialized
knowledge, to apply modern technical and forensic
meansofdetection, fixation, seizure and preliminary
investigation of evidence at the scene. The attention
is focused on the interaction of the investigator
with the specialists, based on the leading role of the
investigator in the conduct of investigative action.
Keywords: criminal offense, special knowledge,
specialist, crime scene investigation, weapons,
ammunition, explosives, illegal weapons.

таннях та відповідях): посібник. К. : Хрещатик, 1996. 199 с.

4. Белкин Р.С. Криминалистика: проблемы сегодняшнего дня. Злободневные вопросы российской криминалистики. М. : Издательство НОРМА (Издательская группа НОРМА-ИНФРА·М), 2001. 240 с.

5. Біленчук П. Д., Кофанов А. В., Сулява О. Ф. Балістика: криміналістичне вогнестрільне зброєзнавство. Підручник. За редакцією проф. П. Д. Біленчука. К.: Міжнародна агенція «BeeZone», 2003. 384 с.

6. Настільна книга слідчого : наук.-практ. видання для слідчих і дізнавачів / Панов М. I., Шепітько В. Ю., Коновалова В. О. та ін. К. : Ін Юре, 2003. 720 c.

7. Мельниченко С. П. Криміналістична характеристика та особливості розслідування незаконного переміщення вогнепальної зброї : дис. ... канд. юрид. наук : 12.00.09. Дніпро: Дніпроп. держ. ун-т внутр. справ, 2016. 207 c.

8. Про затвердження Інструкції про порядок залучення працівників органів досудового розслідування поліції та Експертної служби МВС України як спеціалістів для участі в проведенні огляду місця події : Наказ МВС України від 03.11.2015 р. № 1339. URL: https://zakon.rada.gov.ua/laws/show/ z1392-15. 